\title{
The Anaemic Existence of the Overriding Public Interest in Disclosure in the EU's Access to Documents Regime
}

\author{
Daniel Wyatt ${ }^{*}$ (1)
}

(Accepted 05 August 2019)

\begin{abstract}
According to Regulation 1049/2001, which creates the EU's public access to documents regime, all EU documents should hypothetically be publicly accessible, except for those that fall within explicitly protected interests. A number of these exceptions to disclosure, however, function such that documents covered by them do not have to be disclosed if their release would harm a protected interest unless there is an "overriding public interest in disclosure" exists in the circumstances. The purpose of this Article is to offer a critical examination of this concept of the overriding public interest as interpreted by the Court of Justice of the European Union (CJEU). In the first part, the notion of the public interest generally is discussed from a theoretical perspective. Following this, a thorough analysis of case law concerning the overriding public interest is presented. Finally, this Article presents a critical commentary of the CJEU's understanding of the concept. This Article essentially seeks to argue, inter alia, that the CJEU's interpretation has resulted in democratically unaccountable bureaucrats of the EU effectively becoming the sole arbiters of the existence and content of the overriding public interest in disclosure under Regulation 1049/2001, a situation that is fundamentally unsatisfactory.
\end{abstract}

Keywords: European Union; transparency; access to documents; public interest; jurisprudence of the Court of Justice of the European Union

\section{A. Introduction: Transparency in the EU and the Public Interest in Disclosure of a Document}

The EU seems to exist in a permanent crisis of democracy, with debate incessantly ongoing about the "democratic deficit," as well as the legitimacy of the EU project more generally. ${ }^{1}$ These failings, it has been argued, have resulted in any number of significant problems, with perhaps the most visible one being the rapid and consistent rise of Eurosceptic populism. ${ }^{2}$ One of the primary mechanisms envisioned to combat these perceived democratic shortcomings has been the promotion and operationalization of the principle of transparency within the EU. The importance theoretically afforded to transparency in being able to cure such ills is reflected

${ }^{\star} \mathrm{PhD}$ Candidate, University of Helsinki. I would like to thank Päivi Leino-Sandberg for her always valuable comments. The usual disclaimer applies.

${ }^{1}$ See e.g., Juliet Lodge, Transparency and Democratic Legitimacy, 32 J. Common Mkt. Stud. 343, 343 (1994); Andrew Moravcsik, In Defence of the 'Democratic Deficit': Reassessing Legitimacy in the European Union, 40 J. COMMON MKT. STUD. 603, 603 (2002); Debating the Democratic Legitimacy of the European Union (Beate Kohler-Koch \& Berthold Rittberger eds., 2007); Simon Hix, What is Wrong with the European Union and How to Fix It? (2008).

${ }^{2}$ Emmanouil Mavrozacharakis, Styalianos I. Tzagkarakis \& Apostolos Kamekis, Brexit: A Consequence of the European Social and Democratic Deficit, (2017) (Working Paper) (on file with Social Science Open Access Repository) 2017), www.ssoar.info/ssoar/handle/document/51586.

(c) The Author(s), 2020. Published by Cambridge University Press on behalf of the German Law Journal. This is an Open Access article, distributed under the terms of the Creative Commons Attribution licence (http://creativecommons.org/licenses/by/4.0/), which permits unrestricted re-use, distribution, and reproduction in any medium, provided the original work is properly cited. 
directly in the goals of the European Treaties of an increasingly closer Union where decisions are to be taken as openly and closely to the citizen as possible, ${ }^{3}$ and, perhaps more importantly, a practical citizen and resident right of access to EU documents. ${ }^{4}$ From a concrete legal perspective, the highlight for those arguing in favor of increased EU transparency came in the form of the 2001 enactment of the Access to EU Documents Regulation 1049/2001 (hereinafter Regulation 1049/2001).

The pre-Lisbon Treaty Regulation 1049/2001 sets out a seemingly expansive transparency regime applicable to the EU institutions and its agencies. ${ }^{5}$ It was brought to life to "give the fullest possible effect to the right of public access to documents," so that, effectively, "all documents of the institutions should be accessible." 7 On top of this general strong principle of openness, Regulation 1049/2001 further emphasizes that documents relating to legislative matters should be even more openly available than other documents. ${ }^{8}$ Regulation 1049/2001 recognizes, however, that not all documents should be necessarily accessible by the public and therefore carves out a series of exceptions to the general principle of widest possible access that are grouped into two categories. $^{9}$

The first category of exceptions are mandatory, meaning that if any apply to a document in a given instance then that document must not be disclosed by the holding institution. ${ }^{10}$ The mandatory exceptions seek to protect public security, defense and military matters, international relations, the financial, monetary, or economic policy of the EU or a Member State, and finally the privacy and integrity of the individual. ${ }^{11}$ Although fascinating in their own right, this Article will not deal with the mandatory exceptions any further.

The second category is discretionary. This group of exceptions includes, inter alia, situations where release of a document would undermine the protection of court proceedings and legal advice, the commercial interests of a natural or legal person, or where the release of a document relating to a decision yet to be taken by an institution would seriously undermine the protection of that institution's decision making process. ${ }^{12}$ Adopting a different logic to the mandatory exceptions above, when applying these exceptions, the institutions can refuse access to a document based upon them unless an "overriding public interest in disclosure" (hereinafter OPID) exists with respect to the document. What this means is that if an institution considers that any of these exceptions apply to a document, they must still-in theory-determine first whether, in the circumstances, a public interest in disclosure exists and then weigh that interest against the harm that might result to the interest protected by the exception. As its name suggests, the OPID can therefore serve to override the potential harm to the protected interest and thereby compel the institution to nevertheless disclose the document. This Article aims to engage in an in-depth exploration of this concept of the OPID.

\footnotetext{
${ }^{3}$ Consolidated Version of the Treaty on European Union art. 1, Oct. 26, 2012, 2012 O.J. (C 326) 13 [hereinafter TEU]; Consolidated Version of the Treaty on the Functioning of the European Union art. 15, May 9, 2008, 2008 O.J. (C 115) 47 [hereinafter TFEU].

${ }^{4}$ TFEU art. 15(3); Charter of Fundamental Rights of the European Union art. 42, Oct. 26, 2012, 2012 O.J. (C 326) 391.

${ }^{5}$ Commission Regulation 1049/2001 of the European Parliament and of the Council of 30 May 2001 Regarding Public Access to European Parliament, Council and Commission Documents, 2001 O.J. (L 145) 43 (EC).

${ }^{6} \mathrm{Id}$. at pmbl. 9.

${ }^{7} I d$. at pmbl. 11 .

${ }^{8} I d$. at pmbl. 6.

${ }^{9}$ Id. at art. 1(a).

${ }^{10}$ For a discussion about mandatory exceptions, see Dariusz Adamski, How Wide is the 'Widest Possible'? Judicial Interpretation of the Exceptions to the Right of Access to Official Documents Revisited, 46 COMMON MKT. L. REV. 521, 523-29 (2009).

${ }^{11}$ Commission Regulation 1049/2001, of the European Parliament and of the Council of 30 May 2001 Regarding Public Access to European Parliament, Council and Commission Documents, art. 4(1), 2001 O.J. (L 145) 43 (EC).

${ }^{12} I d$. at arts. $4(2-4)$.
} 
The OPID is a seemingly vital part of the EU's institutional transparency framework. By allowing the public access to documents that still technically fall within an exception to disclosure, the concept on its face operates as a means of balancing the eternally competing goals of institutional secrecy and transparency. It reads as an explicit acknowledgment by the EU legislature that even in cases where harm to a protected interest might exist-and might even potentially be significant - the public's interest in receiving access to that document can nevertheless trump an exception to disclosure. It could be argued, therefore, that the OPID directly reflects the fundamental importance afforded to the concept of transparency by both the European Treaties themselves and Regulation 1049/2001 - as well as the general political rhetoric of the EU institutions-as a democratic legitimacy and accountability enhancing mechanism. A distinct problem, however, is that the meaning and operation of the OPID is not at all clear pursuant to the provisions of Regulation 1049/2001, given that no definition nor any real clues as to the nature of its existence are provided. This lack of clarity has meant that the concept's evolution has been left entirely in the hands of the Court of Justice of the European Union (CJEU) which has, as will be explored in detail, resulted in the concept's operation not aligning with its ostensible underlying meaning or purpose.

This notion of what may be called a legal public interest is not, however, a new or original idea appearing only in Regulation 1049/2001. Rather, it is a prominent concept found in many legal systems and in various contexts. It often appears, however, in a manner similar to the OPID: Undefined and amorphous, prima facie capable of meaning many things simultaneously. This Article starts, therefore, by first setting out the definitional problem that underpins the public interest. Second, it discusses the nature and issues surrounding the interpretation and application of the legal public interest in concrete cases. In Section C, some legislative history about the OPID's place in Regulation 1049/2001's exceptions to disclosure regime is given, and then a detailed exploration of the CJEU jurisprudence relevant for understanding the current nature and content of the OPID is provided. Section D provides an analysis and critique of the OPID as interpreted by the CJEU. Finally, Section E offers some concluding thoughts.

What I aim to illustrate in this Article is that the CJEU's current understanding of the OPID does not reflect the fundamental commitment made to transparency by the EU. I argue that the concept as it now exists actually, paradoxically, acts to reinforce the classic EU paradigm of institutional secrecy and information control. It does this by placing the power with respect to the administration and interpretation of the public interest almost entirely into the hands of the institutions - meaning the unelected and unaccountable institutional bureaucrats working behind the scenes-by leaving essentially no ability on the part of applicants for documents to seek judicial review of the decisions of the institutions with respect to the OPID. The ultimate conclusion, therefore, is that change-either judicial or legislative-is necessary if the concept is to have any practical, or even symbolic, meaning in Regulation 1049/2001's transparency regime. In reaching this finding, the appropriateness or acceptability of a legal public interest test in the EU context is also brought into question.

\section{B. The Public Interest: Background Considerations}

\section{Conceiving the Public Interest}

The public interest is a notoriously slippery concept that does not lend itself readily to definition. Since its apparent birth in ancient Greece, the meaning of the term has been consistently and aggressively debated, with one commentator noting that there are now "as many theories ... as there are writers on the subject." ${ }^{13}$ This has unsurprisingly led to the public interest existing

\footnotetext{
${ }^{13}$ Aileen McHarg, Reconciling Human Rights and the Public Interest: Conceptual Problems and Doctrinal Uncertainty in the Jurisprudence of the European Court of Human Rights, 62 MoD. L. REv. 671, 674 (1999). For a brief intellectual history of the concept, see Alexander Bělohlávek, Public Policy and Public Interest in International Law and EU Law, CzECH Y.B. INT'L L. 117, 123-35 (2012).
} 
as a sort of "conceptual muddle," 14 or, at the more extreme end of the spectrum, "an unanalyzable abstraction so vague in meaning that it cannot be employed for any useful purpose." ${ }^{\prime 5}$ One of the more famous attempts to enunciate a definition of the public interest was in 1955 by popular political commentator and journalist Walter Lippmann who provided that the concept "may be presumed to be what [people] would choose if they saw clearly, thought rationally, acted disinterestedly and benevolently." ${ }^{.6}$ Such a formulation, however, clearly does not hit the nail on the head, so to speak, regarding the concept given that it seems to suggest an almost obvious homogeneous public interest if all individual peculiarities are somehow stripped away. In a modern individualistic, pluralistic, globalized, and fractured society, such a conception of the public interest appears unsatisfying at best.

More usefully, perhaps, Sorauf, in his-admittedly dated, though still highly relevant-critique of the concept, sets out five broad types of definitions that are usually put forward, noting, however, that generally the literature on the public interest is "virtual chaos." 17 The first category sees the public interest as a commonly held value, something that, although perhaps not held by every member of society, is accepted by a large number of society. ${ }^{18}$ The second category views the public interest as the wise or superior interest, meaning an interest that its supporters-which might not necessarily be a majority of society-claim is particularly desirable and should trump other related interests. For example, Sorauf claims that the notion of the "consumer interest" is often viewed in this way. ${ }^{19}$ Third, the public interest can be viewed as a moral imperative. For instance, those who subscribe to a belief in natural law might understand the public interest in this way. ${ }^{20}$ The fourth category understands the public interest to be a balance of relevant interests; however, it depends entirely on the writer as to whether the notion of the public interest is found in the balancing itself or is the result of that balancing act. ${ }^{21}$ Finally, the concept can be conceived of as undefined, a notion that is, in essence, a "political je ne sais quois." 22 Under this view, the public interest is so personalized that it naturally defies any consensus or agreement regarding its existence.

It seems, therefore, that to speak of the public interest is to speak of inherent disagreement and confusion. Or, perhaps more correctly, it is to speak of something so personalized, abstract and context-bound that to make any sort of generalized statements about its existence is next to impossible or even essentially pointless-unless, of course, one is to approach the topic from a very particular ideological or moral perspective. Being left none the wiser about the overarching concept of the public interest, the investigation into the OPID begins, therefore, on relatively shaky ground.

\section{Adjudicating the Public Interest}

In enunciating the, admittedly trite, conclusion that the public interest as a general overarching concept is inherently amorphous or chameleon-like, the way in which the concept is interpreted or adjudicated once it is a legal norm becomes an obvious and significant issue. In other words, as soon as we have a legal test that involves an undefined public interest—as, for example, we have with the OPID - the question that then arises is the nature of the role of the courts in deciding its meaning in concrete cases, and, on an even more theoretical level, is it even appropriate or

\footnotetext{
${ }^{14}$ Frank Sorauf, The Conceptual Muddle, in Nomos V: The Public InTerest (Carl Friedrich ed., 1962).

${ }^{15}$ Julius Cohen, Legisprudence: Problems and Agenda, 11 Hofstra L. Rev. 1163, 1173 (1983).

${ }^{16}$ Walter Lippmann, The Public Philosophy 44 (1955).

${ }^{17}$ Frank Sorauf, The Public Interest Reconsidered, 19 J. OF PoL. 616, 618 (1957).

${ }^{18} I d$. at 619.

${ }^{19} \mathrm{Id}$. at $619-21$.

${ }^{20} \mathrm{Id}$. at 622.

${ }^{21} I d$. at $622-23$.

${ }^{22} I d$. at $623-24$.
} 
desirable for the judiciary to be dealing with matters of the public interest in the first place? Should public interest matters be dealt with instead only by other actors, for example elected representatives? This section deals with these questions in turn.

First, it is necessary to recognize that this concept of the public interest is something that is seen consistently in all manner of legal systems and areas of law, including in the EU. Perhaps most notably in European Union law, the European Court of Justice (ECJ) has held that the free movement of goods may only be restricted by Member States pursuant to any express derogations in the Treaty itself or where its restriction is justified by "overriding reasons in the public interest." ${ }^{23}$ Similarly, in the field of environmental protection, Council Directive 92/43/EEC concerning the conservation of natural habitats provides that a plan or project that receives a negative environmental assessment shall, regardless of this fact, still be undertaken "for imperative reasons of overriding public interest." ${ }^{44}$ Finally, we can find this notion of the abstract public interest in the important doctrine of legitimate expectation, according to which a prima facie legitimate expectation may be trumped by an overriding or higher public interest. ${ }^{25}$ This brief overview shows that the concept can be seen in multiple instances in various forms throughout European Union law.

The central theme that can be extracted from an analysis of these legal public interest tests-as well as the other possible examples - is that they all involve a balancing act by the judges of the interests relevant to the situation at hand, an idea that accords with Souraf's fourth view of the concept. The notion that the public interest is essentially a mechanism which signals that the court is to engage in a balancing of conflicting interests appears to be, in the circumstances, the most reasonable conclusion of the concept's nature. This is because, first, the act of balancing is a natural part of what a judge is required to do on a day-to-day basis. Second, out of Soraufs options sketched above, its existence as a balancing mechanism is arguably the least objectionable. That is, the court cannot choose to leave the public interest entirely undefined, and nor is it appropriate for a court to view the concept in the first three ways proposed by Sorauf-unless, of course, they have been explicitly asked to do so by the legislature, a situation which is important but not relevant for this contribution. Nevertheless, the balancing required with respect to the public interest naturally raises some important questions.

Even though courts are often tasked with interpreting an undefined legal public interest, we may well then ask whether the judiciary is the body most appropriate to decide what is, or what is not, in the public interest in any given case. Quite apart from interpreting the law, ruling on an undefined legal public interest - which, as just explained, generally means essentially balancing all relevant interests at stake with respect to a particular issue and finding the most important or "overriding" interest or interests-is arguably something else altogether and is instead perhaps better understood as an extension of the democratic process. For example, former United Kingdom Attorney General Jeremy Wright argued in a 2016 speech that in many circumstances, an elected and democratically accountable official-rather than an impartial and independent judiciary-is most appropriately placed to makes decisions with respect to this issue. ${ }^{26}$

\footnotetext{
${ }^{23}$ See, e.g., Case C-265/06, Comm'n v. Portugal, 2008 E.C.R. I-02245, para. 38. Further, similar, if not functionally identical, public interest restrictions exist also with respect to the other fundamental freedoms. For example, with respect to the free movement of workers, see generally Case C-415/93, Union royale belge des sociétés de football association and Others v. Bosman and Others, 1995 E.C.R. I-04921, or the free movement of capital, see generally Case C-367/98, Commission v. Portugal, 2002 E.C.R. I-04731.

${ }^{24}$ Council Directive 92/43, art. 6(4), 1992 O.J. (L 206) 7 (EC).

${ }^{25}$ See, e.g., Case 74/74, Comptoir national technique agricole (CNTA) SA v. Comm'n, 1975 E.C.R. 00533; Case C-152/88, Sofrimport SARL v. Comm'n, 1990 E.C.R. I-02477; Case C-189/89, Spagl v. Hauptzollamt Rosenheim, 1990 E.C.R. I-04539; Joined Cases C-104/89 and C-37/90, Mulder and Heinemann v. Council and Comm'n, 1992 E.C.R. I-03061.

${ }^{26}$ Attorney General Jeremy Wright, Address at University College London's Law Faculty on his role as a guardian of the public interest (Feb. 9, 2016), www.gov.uk/government/speeches/the-attorney-general-on-who-should-decide-what-thepublic-interest-is.
} 
Similarly, some political theoreticians have argued that the public interest should be understood as that interest which emerges from deliberative democratic processes, meaning that courts are in no position to determine the public interest in any case. ${ }^{27}$

It is not hard to understand the thrust of these arguments; after all, it seems natural to say that the role of a democratically elected representative is, if anything, to distill and pursue this abstract notion of the public interest-whatever that may actually mean-in their work. The judiciary, however, works to resolve legal problems that arise from these representatives placing their balancing of the public interest - in the form of concrete policy-into hard law. Although these are obvious over-simplifications, the idea that judges may not be particularly well-placed to decide the public interest is clearly something to which attention should be drawn. A slightly different point, though nonetheless related, has been made by Harlow, for example, who, on the topic of public interest litigation in the UK, argued that infusing the law with the notion of the public interest has the potential to politicize the courts by requiring them to make what are essentially political decisions. ${ }^{28}$

One may therefore ask what the utility of the public interest as a legal concept is at all. If it is inherently vague and amorphous and may in many, if indeed not all, cases be better dealt with by elected representatives, why is it a consistently recurring aspect of the law? It seems likely that the term consistently appears in large part because of its vagueness, not in spite of it. As noted elsewhere, again by Sorauf, the public interest is often essentially a placeholder for the legislature, in that it enables the foregoing of making difficult and contentious decisions-that is, providing explicit and specific definitions as to what it considers to be "the public interest" within the context of new pieces of legislation - and postpone them "to more propitious times and circumstances." ${ }^{29}$ The courts may therefore be given the ability to interpret and apply their understanding of the public interest merely because politicians were essentially unwilling or unable to resolve this issue at the time of legislative debate. A similar logic can also be applied to the existence of judge-made public interest tests, such as the restriction upon the right to free movement test noted above.

It is nevertheless important to recognize the clear, positive aspects that exist in the undefined vagueness of the legal concept. This allows the court to take into account whatever may be deemed relevant without being bound by potentially strict legislative definitions. In this way, the public interest can evolve organically depending on the particular circumstances of the case and the point in time that the interpretation is taking place without the need for legislative amendment. ${ }^{30}$ Nevertheless, this element of desirable flexibility again assumes that the judicature is the appropriate engine to be engaging in such an activity, something that is not at all clear, not least because such vague notions clearly give leeway for-amongst other things - acts of questionable judicial activism, something that should be limited as much as possible.

A final point to be made here concerns the appropriateness, or even theoretical possibility, of a legal public interest in the EU in general. As opposed to other more developed legal and political systems, the EU is rather unique in its political immaturity and lack of a demos. ${ }^{31}$ In this way, it is quite difficult to conceptualize what might actually be in the public interest in this system where there is no established understanding-as well as no means of developing such an understanding - of what is "right" and what is "wrong," for lack of better phrasing. The utilization of an undefined public interest at all in the EU appears, therefore, to be a questionable exercise and one that should at some point be subject to significant theoretical scrutiny.

\footnotetext{
${ }^{27}$ See, e.g., Ian O'Flynn, Deliberating about the Public Interest, 16 RES PUBLICA 299 (2010).

${ }^{28}$ Carol Harlow, Public Law and Popular Justice, 65 MOD. L. REV. 1, 5 (2002).

${ }^{29}$ Sorauf, supra note 17 , at 639 .

${ }^{30}$ For a similar point, see Ilanah Fhima, The Public Interest in European Trade Mark Law, INTELL. Prop. Q. 311, 311-12 (2017).

${ }^{31}$ For a fascinating piece on the lack of a single European demos, see generally Francis Cheneval \& Frank Schimmelfennig, The Case for Democracy in the European Union, 51 J. Common MKT. STUD. 334 (2013).
} 
Despite these sorts of critical arguments regarding its place as an element in the law, the undefined public interest is a clearly entrenched legal concept, including in the EU. The most important takeaway from the above analysis may be, therefore, that the public interest will almost invariably be understood by the courts as an invitation to engage in a difficult balancing of relevant interests, whatever they may be in a concrete case. Given this conclusion, one would also therefore tend to expect to see the OPID as interpreted by the CJEU existing in a similar manner. As will be explored, however, the situation with respect to this concept, that is seemingly central to the operation of Regulation 1049/2001, is undoubtedly more complicated.

\section{The Overriding Public Interest in Disclosure in Regulation 1049/2001}

\section{Legislative History of the Concept}

The original Commission proposal for Regulation 1049/2001 contained no overriding public interest test for any of its staggering list of exceptions. ${ }^{32}$ The first institutional suggestion - seemingly following relatively significant external criticism, particularly from the UK House of Lords ${ }^{33}$ - that a public interest in disclosure should be a functional aspect of the EU's new transparency regime was in a European Parliament Report responding to the Commission proposal. There it was noted that a harm test should be included in the new legislation that would require the institutions to weigh the protection of excepted interests against the public interest in having access to the documents. ${ }^{34}$ The inclusion of such a test was also in keeping with the institutions' previous transparency systems, where the CJEU had held that the institutions were required as a matter of course to engage in a similar balancing of interests when applying any exception to disclosure. ${ }^{35}$ Following the Report, the idea caught hold in the legislative negotiations and, after a number of successive, but not particularly illuminating, amendments, the discretionary exceptions ultimately ended up in their current form. ${ }^{36}$

The OPID in the exceptions was, therefore, meant to function as a harm test, requiring the institutions to engage in a substantive balancing of relevant interests whenever they seek to withhold a document on the basis of a discretionary exception. In this way, the original purpose of the OPID was seemingly in keeping with Sorauf s fourth view of the public interest outlined above- that is, the public interest as some sort of balancing mechanism - the view that has been generally adopted by courts interpreting the undefined legal public interest. The available legislative history does not, however, reveal how the legislature envisioned that that balancing act was to be undertaken or give examples of potential public interests that may serve to override any of the exceptions. In other words, it is unclear what theoretically may constitute an overriding public interest under Regulation 1049/2001. Is a public interest found in the substance of a document-for example, that it relates to a particular issue of public interest, such as the environment or fundamental rights—or is it in the relevance of the document with respect to public debate on a particular issue?

Due to the lack of any specific guidance in Regulation 1049/2001, the development of the OPID has therefore been left entirely in the hands of the CJEU. As will be shown below, the EU judiciary has not really chosen to develop the OPID test according to its original legislative conception, and, in doing so, it also has not answered the question regarding what it is that might actually constitute a public interest under the OPID. The CJEU's interpretation has also resulted in the institutions'

\footnotetext{
${ }^{32}$ Commission Proposal for a Regulation of the European Parliament and of the Council Regarding Public Access to European Parliament, Council and Commission Documents, COM (2000) $30 \mathrm{final} / 2$ (Apr. 30, 2008). In fact, this proposal, if passed in its original form, would have essentially given the institutions the ability to keep all of their documents secret.

${ }^{33}$ Select Committee on European Communities, SiXteenth Report: 1999-2000 HL (UK).

${ }^{34}$ Report on the Proposal for a Regulation of the European Parliament and of the Council Regarding Public Access to European Parliament, Council and Commission Documents, Eur. PArL. Doc Final A5-0318/2000 at 12-13, g1 (2000).

${ }^{35}$ See, e.g., Case T-194/94, Carvel v. Council, 1995 E.C.R. II-02765.

${ }^{36}$ For a useful database containing all relevant legislative documents relating to Regulation 1049/2001, 2001 O.J. (L 145) 43 (EC), see www.statewatch.org/secret/observatory.htm.
} 
publicly unaccountable bureaucrats essentially becoming, through their day-to-day administration of access to documents requests, the essentially discretionary arbiters of what constitutes an OPID in the EU. The desirability of this situation will be discussed in Section D.

\section{The Jurisprudential Evolution of the Concept}

The logical starting point in any attempt to understand how the OPID in Regulation 1049/2001 came to be in its current form is the landmark 2008 ECJ case of Turco. ${ }^{37}$ In this case, Mr. Turco, the Appellant, requested from the Council access to, inter alia, a legal opinion of the Council's Legal Service concerning a directive on the topic of the minimum standards for the reception of asylum seekers. The Council refused to disclose the legal opinion, arguing that to do so would undermine the protection of legal advice pursuant to Article 4(2) of Regulation 1049/2001. Mr. Turco appealed the decision to the Council arguing, inter alia, that "the principle of democracy and citizen participation in the legislative process constitutes an overriding public interest in the disclosure of, inter alia, the legal opinion in question." ${ }^{38}$ In its reply, the Council argued that the general interest of increased transparency and openness of the institutions cannot constitute the basis of an OPID as this would have the effect of making all documents of a similar nature automatically disclosable, thereby depriving the exception to disclosure in Article 4(2) of Regulation 1049/2001 of any practical effect. ${ }^{39}$ The Court of First Instance effectively sided with the arguments of the Council in rejecting Mr. Turco's request for annulment of the Council's decision. ${ }^{40}$ On appeal Mr. Turco was more successful, though, with the ECJ intimating that the concept of an OPID would be given an important role in the context of Regulation 1049/2001's discretionary exceptions to disclosure moving forward.

The ECJ noted that the institution must carry-out a three-stage assessment in its application of the Article 4(2) exception relating to legal advice. According to the test, the institution must first, be satisfied that the document, or parts of that document, actually relate legal advice; ${ }^{41}$ second, assess whether disclosure of the document or the parts of the document covered by the exception would actually undermine a protected interest in a "reasonably foreseeable and not purely hypothetical" manner; ${ }^{42}$ and, finally, "ascertain whether there is any overriding public interest justifying disclosure" regardless of whether they have determined that the interest protected by the exception would be undermined. ${ }^{43}$ The institution in question, therefore, must be the one to "balance the particular interest to be protected ... against, inter alia, the public interest in the document being made accessible in light of the advantages stemming ... from increased openness," ${ }^{4}$ bearing in mind the fact that legislative documents-such as the legal advice in question-are subject to a wider concept of public access. ${ }^{45}$

After first holding that the risk of the protection of legal advice being undermined was not foreseeable and was purely hypothetical, the Court then went on to provide that an OPID also existed, with the Council carrying out an incorrect assessment on the matter. In a relatively strong statement concerning the concept, the Court said that:

An overriding public interest is constituted by the fact that disclosure of documents containing the advice of an institution's legal service on legal questions arising when legislative initiatives are being debated increases the transparency and openness of the

\footnotetext{
${ }^{37}$ Joined Cases 39 \& 52/05 P, Sweden and Maurizio Turco v. Council, 2008 E.C.R. I-04723.

${ }^{38} I d$. at para. 12 .

${ }^{39} I d$. at para. 13 .

${ }^{40}$ Case T-84/03, Maurizio Turco v. Council, 2004 E.C.R. II-04061.

${ }^{41} I d$.; Sweden and Maurizio Turco, Joined Cases 39 \& 52/05 P at paras. 38-39.

${ }^{42}$ Sweden and Maurizio Turco, Joined Cases $39 \& 52 / 05$ P at paras. 40-43.

${ }^{43} \mathrm{Id}$. at para. 44.

${ }^{44}$ Turco, Case T-84/03; Sweden and Maurizio Turco, Joined Cases 39 \& 52/05 P at para. 45.

${ }^{45}$ Sweden and Maurizio Turco, Joined Cases $39 \& 52 / 05 \mathrm{P}$ at para. 46.
} 
legislative process and strengthens the democratic right of European citizens to scrutinize the information which has formed the basis of a legislative act. ${ }^{46}$

Based largely on the above analysis, the Court went on to say that legal advice concerning a legislative process is therefore prima facie disclosable unless the legal opinion is "of a particularly sensitive nature" or has a "particularly wide scope that goes beyond the context of the legislative process in question." ${ }^{\prime 7}$ The evolution of the concept of an OPID began, therefore, on relatively solid ground - at least with respect to legislative documents-with the ECJ engaging substantively with the issue. Following Turco, however, the ECJ rather dramatically changed its course.

In cases such as Technische Glaswerke Ilmenau, ${ }^{48} \mathrm{API},{ }^{49}$ and $L P N,{ }^{50}$ a strand of interpretation of the OPID emerged that required the person applying for documents to prove "specific circumstances" to show that the "principle of transparency was in some sense especially pressing," with "general considerations" being insufficient to do this. At no point was or has this interpretation been justified or expanded upon by the ECJ. The problem with requiring an applicant to prove this is that, as argued by Sweden in $L P N$, the institution holding the document is the only one with knowledge of its contents and, by extension, the only one practically in a position to allege specific circumstances of the sort required. ${ }^{51}$ The case law following the embedding of this new way of interpreting the OPID clearly bears out this fundamental paradox. Through an analysis of two additional cases, Access Info and Pari Pharma, what follows will show how the CJEU's interpretation of the OPID post-Turco has resulted in its existence not as a balancing harm test, but rather as an aspect of Regulation 1049/2001 which paradoxically acts to reinforce, rather than counteract, institutional secrecy.

Access Info concerned a request for documents to the Commission by the applicant, Access Info, regarding a migrant agreement between Turkey and the EU entered into to respond to the European migrant crisis of 2015. An important aspect of this agreement was that all irregular migrants crossing from Turkey into Greece would be returned to Turkey at the cost of the EU and that for every Syrian returned according to that procedure another Syrian would be resettled in an EU Member State. ${ }^{52}$ Access Info was concerned about the deal's compatibility with international human rights law and the Commission's investigation of its legality and therefore sought to obtain relevant pieces of legal advice or analysis regarding the agreement. ${ }^{53}$ The Commission denied access to a number of identified documents. According to the Commission, a conclusion with which the General Court agreed, the documents fell within the exceptions provided for in Article 4(1) of Regulation 1049/ 2001 concerning the protection of the public interest in international relations - a mandatory exception and therefore not relevant here-and in Article 4(2) concerning the protection of court proceedings and legal advice, both discretionary exceptions.

With respect to the OPID, the Court first noted the applicant's arguments that an OPID existed in this instance because: First, the institutions of the EU can only be held accountable and demonstrate the legitimacy of their decisions through the citizens being able to understand the legal context in the making of those decisions; and second, that the seriousness of the migrant crisis and the measures taken by the EU to deal with it are sufficient reasons to justify the existence of an OPID in this case. ${ }^{54}$ Access Info also argued that the Commission failed to examine whether a

\footnotetext{
${ }^{46} I d$. at para. 67.

${ }^{47} \mathrm{Id}$. at paras. $68-69$.

${ }^{48}$ Case C-139/07 P, Comm'n v. Technische Glaswerke Ilmenau, 2010 E.C.R. I-05885.

${ }^{49}$ Case C-514/07 P, Sweden and Others v. API and Comm'n, 2010 E.C.R. I-08533.

${ }^{50}$ ECJ, Case C-514/11 P, LPN and Finland v. Comm'n, ECLI:EU:C:2013:738, Judgement of 14 Nov. 2013.

${ }^{51} I d$. at para. 88 .

${ }^{52}$ European Council Press Release, Statement of the EU Heads of State or Government (Mar. 8, 2016), www.consilium. europa.eu/en/press/press-releases/2016/03/08/eu-turkey-meeting-statement/.

${ }^{53}$ ECJ, Case T-851/16, Access Info Europe v. Comm'n, ECLI:EU:T:2018:69, Judgement of 7 Feb. 2018, para. 6.

${ }^{54} \mathrm{Id}$. at paras. $97-98$.
} 
public interest in disclosure existed in this case and generally failed to weigh the potential harm against the interests protected under Regulation 1049/2001 against the existence of such an OPID. The Commission argued that the applicant had merely invoked the principle of transparency without providing specific circumstances as to why the "principle of transparency was especially pressing" in this case. ${ }^{55}$ Access Info was ultimately unsuccessful in arguing for an OPID.

According to the Court, the Commission carried out its responsibility to weigh the relevant interests. ${ }^{56}$ Because the applicant only provided arguments that relied on the importance of transparency generally in the democratic system of the EU, however, this was not enough to show that the principle of transparency was especially pressing and therefore capable of overcoming the Commission's grounds for refusal. ${ }^{57}$ The Court did not address the applicant's arguments regarding the fact that the European migrant crisis was an issue of particular public interest, which is confusing considering that the issue at hand was whether there was an OPID. The mere lack of specific circumstances, then, appears to entirely trump any interest the public might have in knowing about how the EU handles human rights issues. ${ }^{58}$

Pari Pharma, in contrast, is notable because unlike the other cases discussed above, it involves a European Union agency attempting to have a document disclosed in the face of a private company trying to keep it secret. ${ }^{59}$ Here, a pharmaceutical company named Novartis, an intervener in this case, was given marketing authorization by the European Medicines Agency (EMA) for a new orphan medicinal product known as TOBI Podhaler (TP).$^{60}$ Having been granted authorization, Novartis subsequently obtained a ten-year period of market exclusivity for TP. Following this, Pari Pharma, the applicant and competing pharmaceutical company, received authorization for a product that would compete directly with TP. The intervener, likely unhappy about losing its monopoly over the market, submitted a request for documents to the EMA, the defendant, for all documents held by it relating to Pari Pharma's authorization application. The EMA agreed to disclose two assessment reports by the EMA's Committee for Medicinal Products for Human Use. The applicant subsequently brought this action before the General Court, seeking to have the EMA's decision to disclose these documents annulled on the grounds that, inter alia, disclosure of the documents would undermine their commercial interests that are protected pursuant to Article 4(2) of Regulation 1049/2001, and, further, that there was no overriding public interest in their being disclosed. The applicant lost on both these counts, and the Court found that an OPID existed with respect to the parts of the documents that the applicant unsuccessfully attempted to argue fell within the relevant exception.

After detailing the parts of the documents that the applicant wished to keep confidential, the Court agreed with the defendant that the information was all "scientific evidence of the clinical benefit of [the drug] for a part of the target population and evidence that the conditions enabling derogation from market exclusivity for TP are met." ${ }^{\prime 1}$ According to the arguments of the defendant, this fact about the pieces of information was enough to justify the existence of an OPID in this case, ${ }^{62}$ a conclusion with which the Court agreed. Restating the now classic formulation noted

\footnotetext{
${ }^{55} \mathrm{Id}$. at para. 99.

${ }^{56} I d$. at para. 109.

${ }^{57}$ Id. at para. 112 .

${ }^{58}$ For more information on this point, see, e.g., Päivi Leino \& Daniel Wyatt, No Public Interest in Whether the EU-Turkey Refugee Deal Respects EU Treaties and International Human Rights?, EUR. L. BLOG (Apr. 9, 2020, 2:13 PM), https:// europeanlawblog.eu/2018/02/28/no-public-interest-in-whether-the-eu-turkey-refugee-deal-respects-eu-treaties-andinternational-human-rights/.

${ }^{59}$ ECJ, Case T-235/15, Pari Pharma GmbH v. European Medicines Agency, ECLI:EU:T:2018:65, Judgement of 5 Feb. 2018.

${ }^{60}$ Orphan medicinal products are those designed to combat rare diseases, the production of which was incentivized by the EU in Regulation 141/2000, of the European Parliament and of the Council of 16 December 1999 on orphan medicinal products, 2000 O.J. (L 18) 1 (EC).

${ }^{61} I d$. at paras. $143,151,163$.

${ }^{62} I d$.
} 
above of the OPID test, the Court held that the specific circumstances threshold showing the principle of transparency to be especially pressing had been passed in this instance ${ }^{63}$ Further, the Court provided that, "although the reasons put forward by the EMA ..."--that is, the above quote regarding their nature as "scientific evidence"- "are admittedly succinct, they do constitute specific circumstances and not purely general considerations justifying disclosure." ${ }^{\prime 4}$ Because of their showing these "admittedly succinct" specific circumstances, the EMA could therefore disclose the parts of the relevant documents at issue.

\section{Analysis and Critique}

\section{Judging the OPID}

Together, these cases reveal the rather unusual nature of the OPID as interpreted by the CJEU. By placing the onus upon the person arguing for the existence of an OPID, the CJEU has essentially stated that that party must have specific knowledge of the document that that they are requesting. In other words, they must have seen the document before requesting it, a paradoxical notion that defeats the very purpose of a document access law in the first place. Therefore, this onus is almost—if not entirely-impossible to shift. ${ }^{65}$ For this reason, decisions made by the institutions - meaning practically institutional bureaucrats - with respect to the OPID become, in essence, not truly subject to judicial review. What was ostensibly originally envisioned to act as a functional harm balancing mechanism responding to the discretionary exceptions and their application-an important element of Regulation 1049/2001 that would force the institutions to truly consider whether the potential harm to a protected interest was more important than public access to a document-has, due to this unfortunate procedural roadblock, become an essentially redundant part of the law, at least from the perspective of citizens.

This roadblock has also resulted in a lack of judicial development of the substance of the public interest in the OPID. It is not possible to glean from the case law what might in practice constitute a public interest for the purposes of the OPID. This is in stark contrast to other similar access to documents regimes where the public interest has seemingly invariably received significant attention from judicial or quasi-judicial bodies, meaning that the situation that can be observed in the EU with regards to the OPID — that is, the CJEU not routinely interpreting and applying the public interest in individual cases-appears to be rather unique. For example, in the UK, a non-restrictive application of a public interest test in their freedom of information regime by courts and tribunals has led to the natural development of its legislatively undefined substance. On this point, the UK Information Commissioner's Office has noted that, based on an analysis of relevant decisions, a public interest may arise from a "general public interest in transparency"; "public interest in the issue,"-for example that a document might shed light on, and foster public debate about, significant changes to take place in the education system; public interest in the specific information; the fact that there might be a "suspicion of wrongdoing"; and, finally, whether the information might help present a "full picture" of, for example, the reasons for decisions issued by a public authority. ${ }^{66}$ Further, a 2007 article by Turle highlights just how developed the public interest in the context of access to documents systems is in countries such as Canada, New Zealand, Ireland, and Australia - the last of which will be discussed in

\footnotetext{
${ }^{63} I d$. at para. 144 .

${ }^{64} I d$.

${ }^{65}$ For a similar argument on a related issue, see Deirdre Curtin \& Päivi Leino, In Search of Transparency for EU LawMaking: Trilogues on the Cusp of Dawn, 54 Common Mкт. L. Rev. 1673, 1707 (2017).

${ }^{66}$ The Public Interest Test: Freedom of Information Act [FOIA], (2000), at 11-15 (Eng.), https://ico.org.uk/media/fororganisations/documents/1183/the_public_interest_test.pdf.
} 
detail below. ${ }^{67}$ The comparative entire lack of development of the OPID in this regard due to the "specific circumstances" case law must be viewed as disappointing, in particular given that the UK and EU access to documents laws are approximately the same age.

Despite this conclusion that the CJEU's interpretation of the OPID is unsatisfactory, it is nevertheless possible to make the argument that the Court has arrived at a theoretically desirable OPID test. By constructing it in the way that they have, the CJEU has essentially removed their ability to adjudicate on the substance of the public interest, a decision which accords with those who see the judiciary as ill-placed to issue judgment with respect to such matters in the first place. There are, however, several problems with this view. First, the OPID explicitly exists in Regulation $1049 / 2001$ as a functional aspect of the transparency regime. It seems almost inappropriate for the EU courts to have essentially removed themselves from dealing with OPID matters in this way. Second, the CJEU is generally more than happy to rule on public interest matters in various other areas of the law; the case of the OPID is therefore merely a rather significant aberration. ${ }^{68}$ Finally, those who argue against the judiciary holding public interest adjudication powers argue in favor of those decisions being made by democratically elected representatives. In the case of the OPID, these decisions are almost always made by the administrative legal services units in each of the institutions. Democratically accountable actors of the EU are not, therefore, engaging in deliberative discussions regarding the nature of the OPID in concrete access to documents cases, outside of possible mere rubber-stamping of the decisions of the legal services.

One might then, in turn, perhaps consider whether these non-elected members of the institutions' legal services are in fact the people who should be interpreting and applying the public interest according to Regulation 1049/2001. They are undeniable experts in the field who deal with these questions every day in their work. It appears rather unlikely, however, that these officials actually engage in a satisfactory balancing of relevant interests, but instead tend to favor the interests of institutional secrecy when deciding on access to documents requests. With respect to this point, Bart Driessen, a long-time member of the Council's Legal Service, has argued that the institutions do, in fact, sometimes find an OPID when they deal with access to documents requests. Yet, because they are not required to state reasons in the event of a positive decision, this information is not publicized. ${ }^{69}$ Driessen also immediately says that it is nevertheless only on rare occasions that an OPID would be found by the institutions. ${ }^{70}$ This statement from a long-time institutional insider is curious. Why is it, in fact, so rare that that an OPID is found by the institutions when the notion of institutional transparency is given such foundational-and indeed some would say constitutional ${ }^{71}$ — weight in the modern "democratic" European Union? One would perhaps assume that an overriding public interest in disclosure would manifest statistically

\footnotetext{
${ }^{67}$ Marcus Turle, Freedom of Information and the Public Interest Test, 23 CoMpuTER L. \& SECURITY ReV. 167 (2007). The same point can be drawn also from, e.g., Moira Paterson \& Maeve McDonagh, Freedom of Information and the Public Interest: The Commonwealth Experience, 17 OXford U. COMMONwEALTH L. J. 189 (in which the authors survey a significant number of Commonwealth countries' access to documents regimes as regards the public interest).

${ }^{68}$ See supra note 23 and accompanying text for a discussion on the restrictions on the fundamental freedoms. Interestingly, in these cases it is possible to see just how much the CJEU has developed and applied-in other words, engaged in a balancing of relevant interests - the notion of the public interest in various contexts. For example, the Court has held that relevant public interests with respect to the restriction of the free movement of goods include: The effectiveness of fiscal supervision; fairness of commercial transactions; protection of consumer and public health (Case 120/78, Rewe-Zentral AG v. Bundesmonopolverwaltung für Branntwein, 1979 E.C.R. 00649); protection of the environment (Case 302/86, Comm'n v. Denmark, 1988 E.C.R. 04607); protection of animal welfare (Case C-219/07, Nationale Raad van Dierenkwkers en Liefhebbers and Andibel v. Belgium, 2008 E.C.R. I-04475); protection of children (Case C-244/06, Dynamic Medien Vertriebs GmbH v. Avides Media AG, 2008 E.C.R. I-00505); road safety (Case C-54/05, Comm'n v. Finland, 2007 E.C.R. I-02473); and the prevention of fraud (Case C-161/09, Kakavetsos-Fragkopoulos v. Nomarchiaki Aftodiokisi Korinthias, 2011 E.C.R. I-00915).

${ }^{69}$ Bart Driessen, Transparency in EU Institutional Law: A Practitioner's Handbook 70 (2d ed. 2012).

${ }^{70} I d$.

${ }^{71}$ Deirdre Curtin \& Maarten Hillebrandt, Transparency in the EU: Constitutional Overtones, Institutional Dynamics, and the Escape Hatch of Secrecy, in RESEARCH HANDBOOK ON EU InSTITUTIONAL LAW (Adam Lazowksi \& Steven Blockmans eds., 2016).
} 
more often than only on the rare occasion. A significant reason for this happening seems to be the fact that due to the CJEU's specific circumstances doctrine, the institutions do not really have to be worried about their decisions relating to the OPID being opened up by the court. Therefore, the Court can heavily favor institutional secrecy in their decisions.

The OPID as interpreted by the CJEU can be understood to exist, therefore, in a purgatory of sorts. Without specific circumstances being presented by the applicant—which, as discussed, is an effectively, if not actually, impossible threshold-the CJEU will not review the institutions' decisions with respect to the OPID. In this way, the institutions are in practice able to avoid engaging in a true balancing of relevant interests and in the vast majority of cases-taking into account, of course, Driessen's statement that an OPID is actually found on the rare occasion $^{72}$-will tend to favor the interests of institutional secrecy. Therefore, with all of this in mind, some kind of change with respect to the OPID is necessary.

\section{Fixing the OPID}

Working, then, upon the assumption that the OPID is in some sense broken, it is fair to ask what should be done to fix it. Such potential change could be effected in essentially two ways. The first way would be for the CJEU itself to change its course with respect to its OPID jurisprudence by taking the onus away from applicants for documents and placing it upon the institutions. In this way, institutional decisions made regarding the OPID would then be naturally opened to judicial review. Given the seemingly entrenched nature of the current OPID test in the case law of the CJEU, however, this appears incredibly unlikely. We are left then with a second option: Legislative amendment of Regulation 1049/2001.

Although desirable for any number of reasons-Regulation 1049/2001 is, as has been pointed out elsewhere, now outdated in a number of important respects following the introduction of the Lisbon Treaty ${ }^{73}$ - the odds of any sort of amendment are, at least in the short term, quite low. This is because for all intents and purposes, the amendment process regarding Regulation 1049/2001 has effectively stalled, with no break of the deadlock in sight. ${ }^{74}$ The law will likely remain then in its current form for the foreseeable future. Assuming that at some point we will see some change in the law's text, the question then becomes what form a rectified OPID should take. To provide some potential answers to this question, the rest of this section will explore, first, the European Parliament's first reading position in the update of Regulation 1049/2001 with respect to the public interest issue, and, second, the Freedom of Information (FOI) regimes that exist in Australia and Finland respectively.

It is clear that pursuant to the Parliament's amendment text, the notion of the OPID has been targeted as an element of Regulation 1049/2001 that requires some amount of clarification. Interestingly, in the context of the amendment process, the Committee on Petitions even called upon the Commission to "provide an exact and concrete definition of the term," due to confusion surrounding its use. ${ }^{75}$ According to the proposed Article 4(4):

\footnotetext{
${ }^{72}$ Interestingly, I have personally been on the receiving end of a positive OPID decision from the Council with respect to an access to documents request I made. The Council chose to recognize the existence of an OPID only after I made a confirmatory application setting out in some detail arguments refuting their initial refusal to release the requested documents. It appears safe to say that a person who does not work with EU transparency on a day-to-day basis - that is, the vast majority of people making access to documents requests - may have a bit more difficulty in presenting arguments to the institutions to persuade them to change their mind with respect to the OPID.

${ }^{73}$ Dacian Dragos \& Bogdana Neamtu, Freedom of Information in the EU in the Midst of Legal Rules, Jurisprudence and Ombusprudence: The European Ombudsman as Developer of Norms of Good Administration, 13 EUR. CONST. L. REV. 641, 669 (2017).

${ }^{74}$ For a history of the stalled legislative procedure, see Public access to European Parliament, Council and Commission documents, COM (2008) 229 final (Apr. 30, 2008).

${ }^{75}$ Opinion of the Committee on Petitions for the Committee on Civil Liberties, Justice and Home Affairs on the proposal for a regulation of the European Parliament and of the Council regarding public access to European Parliament, Council and Commission documents, COM (2008) 0229 - C6-0184/2008 - 2008/0090 (COD) (Dec. 3, 2010).
} 
When balancing the public interest in disclosure under [the exceptions to disclosure], an overriding public interest in disclosure shall be deemed to exist where the document requested relates to the protection of fundamental rights and the rule of law, sound management of public funds, or the right to live in a healthy environment, including in terms of emissions into the environment. ${ }^{76}$

There are a number of takeaways from this proposed updated notion of the public interest. The first is that the Parliament clearly wishes to explicitly acknowledge the balancing nature of the OPID in the Regulation 1049/2001 regime. Although a seemingly minor point, the significance of this clarification should not be overlooked. Second, and crucially, the text does not specify where the onus is to lie with respect to this balancing of interests. Without an express statement to the effect that that burden is upon the institutions in all instances related to the OPID, the proposed text risks ending up largely in the same state that we see currently, with the exception of the next point to be discussed. Third, the text proposes several interest that have been understood to be so important as to be deemed to constitute an OPID, meaning that neither the institutions nor the courts need to engage in any interest balancing exercises. These types of "deemed OPID" categories, although creating interpretive difficulties of their own, would be a welcome addition to the Regulation 1049/2001 system.

Moving away now from the stalled Regulation 1049/2001 amendment process, it is useful to also look to see how other legal systems - in this case, Australia and Finland-have dealt with effectively the same issue. Looking at Australia's FOI Act first, it seems to operate in a manner similar to the way in which the EU's access to documents regime works. Certain categories of documents are conditionally exempted from having to be disclosed-for example, those that relate to Commonwealth-State relations, personal privacy, business affairs, or the Australian economy. What this means is that these documents must in principle be disclosed by the relevant agency unless public access to the document would be, on balance, "contrary to the public interest." 77 This formulation of the conditional exceptions is, in essence, therefore the reverse of the discretionary exceptions found in Regulation 1049/2001, but the principles which arise in Australia's FOI Act provide a direct and useful comparison.

To help in determining whether the disclosure of a document would be contrary to the public interest, the FOI Act explicitly enumerates four non-exhaustive relevant factors that weigh in favor of a document being disclosed. These are that release of the document would: (1) Promote the objects of the FOI Act; (2) inform debate on a matter of public importance; (3) promote effective oversight of public expenditure; and (4) allow a person to access his or her personal information. ${ }^{78}$ Fascinatingly, the FOI Act also includes a list of factors that are irrelevant for an agency determining the public interest in disclosure, for example, that disclosure of a document could result in embarrassment to the Government or that it could result in confusion or unnecessary debate. ${ }^{79}$ Further, the FOI Act does not set out factors that would weigh against disclosure of the document. This seems to be because the Act sets out in quite significant detail the relevant thresholds of harm applicable to each conditional exception. ${ }^{80}$ Finally, the Act also explicitly places the onus of

\footnotetext{
${ }^{76}$ European Parliament Legislative Resolution of 15 December 2011 on the proposal for a regulation of the European Parliament and of the Council regarding public access to European Parliament, Council and Commission documents (recast), COM (2008) 0229 - C6-0184/2008 - 2008/0090 (COD) (Dec. 15, 2011).

${ }^{77}$ Freedom of Information Act 1982, $\$ 11 \mathrm{~A}(5)$ (Austl.), http://www5.austlii.edu.au/au/legis/cth/consol_act/foia1982222/ s11a.html.

${ }^{78} I d$. at $\$ 11 \mathrm{~B}(3)$.

${ }^{79} \mathrm{Id}$. at $\$ 11 \mathrm{~B}(4)$.

${ }^{80}$ For example, the conditional exception relating to personal privacy provides that a document is exempt if its disclosure "would involve the unreasonable disclosure of personal information." The section then goes on to provide a series of criteria to assist in determining whether disclosure would result in such an "unreasonable disclosure," for example, "the extent to which
} 
establishing that a decision to withhold disclosure of a document was justified upon the relevant agency to which the request was made. ${ }^{81}$

The FOI Act in Finland solves the exception to disclosure and public interest conundrum by outlining, in significant detail, thirty-two separate and extensive exceptions to the general rule of disclosure with no corresponding public interest test. ${ }^{82}$ What this means in practice is that, following a request for documents, the relevant examining authority merely administers the exceptions as written and is not required to engage in any significant interest balancing exercises. This arrangement therefore removes the judgment-based decisions that inevitably arise whenever the public interest exists as an element to be considered. Of course, the interpretations of those specific exceptions by bureaucrats are often appealed to the Finnish courts, however, such cases do not involve ambiguous interest balancing in the same way as a legal public interest test. Rather, these disputes involve more traditional problems of legal interpretation.

All three alternatives sketched above would provide a preferable exception to disclosure mechanism than the one that currently exists under Regulation 1049/2001, at least as far it has been interpreted by the CJEU. They all, however, undoubtedly have their shortcomings. The amendment proposed by the European Parliament would keep the concept in essentially the same form as it currently exists, assuming, of course, that the CJEU would not reverse its current "specific circumstances" jurisprudence. Nevertheless, the "deemed OPID" categories-however they would actually be interpreted-would be a clearly welcome addition from the point of view of increased institutional transparency. The Australian model, however, can be understood as a substantially more transparency friendly version of Regulation 1049/2001's exception system, both the current and proposed versions. Although still involving a public interest test in the broad sense, clearer guidance is given as to the interpretation of the notion of the public interest, conditionally exempt documents are assumed to be disclosed, not kept secret, and the onus is expressly placed upon the relevant agency. Nevertheless, the existence of any sort of public interest test-even if it is, in the case of Australia, more guided and concerns whether the document should not be disclosed-still opens the access to documents process to undeniable ambiguity. Finally, the Finnish model is unique in that it takes the public interest entirely out of the equation; or, perhaps a better way of understanding the situation is that the public interests in non-disclosure were decided at the time of legislative enactment. In doing so, the regime alleviates the concerns held by those who regard actors who are not democratically accountable as inappropriate to be deciding upon the substantive content of the public interest in concrete cases. Further, this model is also preferable if we take seriously the criticism levelled earlier in this Article that the EU in particular should not be dealing with undefined legal public interest tests. Such a system nevertheless has the undeniable potential to be too rigid and not allow for natural societal change, an arguably important concept, particularly vis-à-vis governmental transparency.

The larger point this analysis begs is that there is clearly no perfect solution to the significant problem of balancing the conflicting interests of institutional secrecy and public access to official documents. The issues that arise with respect to the analysis of the OPID exist, therefore, as a sort of microcosm of the more general problem of creating and effecting policy regarding governmental transparency. In reaching this understanding, the question then essentially reverts to where is the most desirable and logical location to place the power to carry-out the actual balancing that must take place between these naturally conflicting dichotomous ends-a question to which there is no easy, or necessarily correct, answer. Nevertheless, regardless of the many differing-and

the information is well known," or "the availability of the information from publicly accessible sources." Id. at $\$ \$ 47 \mathrm{~F}(1)$, $47 \mathrm{~F}(2)(\mathrm{a}), 47 \mathrm{~F}(2)(\mathrm{c})$.

${ }^{81} I d$. at $\$ \$ 55 \mathrm{D}, 61$.

${ }^{82} 621 / 1999$ Act on the Openness of Government Activities, (1999) $\$ \$ 1(1), 24$ (Fin.), https://www.internationalbudget.org/ wp-content/uploads/Finland-ActOntheOpenessofGovtActivities1999-English.pdf. 
likely equally valid-opinions on the matter, it is clear that the CJEU's interpretation of the legislatively vague OPID has produced perhaps the least desirable possible solution. That is, matters of the public interest are being decided by actors working behind the scenes who are not democratically accountable and whose decisions will not, for the aforementioned reasons, be ultimately truly subject to judicial review.

\section{E. Conclusion}

The concept of the OPID is, at least on its black-letter face, not an unimportant part of Regulation $1049 / 2001$. It signifies the value placed upon transparency by the EU as an invaluable aspect of democracy, and, practically, its proper interest balancing operation would result in the disclosure of important documents that would otherwise have remained secret. From the point of view of citizen oversight of, and participation in, the governance of the EU, these points are clearly significant. As discussed in detail throughout this Article, however, the concept's current existence does not function in that way. The analysis presented suggests a number of relevant conclusions.

First, and significantly, based on the CJEU's restrictive jurisprudence, it is essentially impossible to identify what it actually is or could be that constitutes a public interest in the context of the OPID. Is it the substance of the document, the ability of the document to help achieve a particular-for example, democratic_-purpose, or both of these things, or indeed something else, such as the ability of a document to form a complete picture of the internal workings of the institutions? Further, and flowing from this point, the Court has also not provided any reasoning regarding how the balancing of the relevant interests-whatever they may be-should be performed in concrete cases.

The interpretation and application of the OPID has therefore been left almost solely in the hands of the democratically unaccountable institutional bureaucrats of the EU. Due, in at least part, to the restrictive specific circumstances doctrine developed by the Court, the public servants dealing with access requests only rarely find the existence of an OPID, despite the constitutional nature of transparency as a democratic value in the European Union. It seems quite clear that if democratically accountable actors of the EU are not deciding upon the nature of the OPID-for example, by legislating an extensive definition - then at the very least, the decisions of the bureaucrats regarding the concept should be routinely opened up by the CJEU whenever an access to documents case comes before it, without the need for essentially impossible proof needing to be presented by applicants.

On a practical level, the Australian FOI Act in particular may offer the most appropriate and concrete model upon which to improve the Regulation 1049/2001's public interest test moving forward. The Australian FOI Act's presumed disclosure of conditionally exempt documents would, if introduced into Regulation 1049/2001, significantly and positively impact the operation of the OPID test. By making disclosure the assumed position, the institutions would necessarily have to provide more significant reasoning regarding their choice to protect an excepted interest over the public interest in disclosure. Further, and although by no means a perfect solution, enumerating a non-exhaustive list of factors weighing in favor of an OPID, and indeed perhaps a list of irrelevant factors, would also be of significant practical utility. Finally, explicitly placing the onus of proof upon the responsible institution in order to do away with the specific circumstances system manufactured by the CJEU would be most welcome. These types of changes would still allow the institutions to withhold protected documents, but only when it would be absolutely necessary that they do so, which is surely the way in which Regulation 1049/2001—which is based on a presumption of openness-should function in the first place.

Cite this article: Wyatt D (2020). The Anaemic Existence of the Overriding Public Interest in Disclosure in the EU's Access to Documents Regime. German Law Journal 21, 686-701. https://doi.org/10.1017/glj.2020.37 